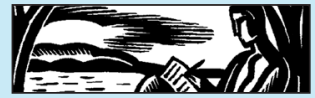

\title{
Prison Letters: Spain Confronts Its Past
}

\author{
Martyn Lyons
}

University of New South Wales

\section{ABSTRACT}

In post-Franco Spain, the families of the regime's victims, as well as other republican supporters, have not only struggled to recover the bodies of victims of the repression, but also have tried to recover a lost historical memory after years of imposed silence. Véronica Sierra Blas's new study of Franco's prisoners (there were approximately 280,000 of them) aims to give recognition and some human dignity to their obscure fate. This article offers a critical discussion of her study of a corpus of about 1500 letters written by prisoners during the Spanish Civil War and the subsequent Francoist repression. They include petitions to the authorities, messages secretly smuggled out of jail, and the 'chapel letters' written by condemned prisoners on the eve of their execution. Many of the latter were designed to be made public for propaganda purposes. This article suggests that as those condemned to execution reviewed their lives, their final farewells constituted a form of life writing in the face of certain death.

Keywords: Spanish Civil War; prison letters; petitions

In 1977, after the death of Franco, an amnesty law released all remaining political prisoners in Spain, and ensured that there would be no prosecution of the previous regime or of abuses committed during the dictatorship. To prevent civil conflict happening again, it was best to forget about holding trials for abuses of human rights, truth and reconciliation commissions, war crimes commissions and the like. A peaceful transition to democracy depended, it seemed, on a consensus formed around amnesia. The Spanish people agreed to pretend not to remember the trauma of the repression. 
This, however, was only a temporary solution. By the $70^{\text {th }}$ anniversary of the outbreak of the Civil War (2006), Spain was a stable democracy and it was high time for some public acknowledgment of the violence and its victims. The Law of Historical Memory accordingly recognized the victims of Franco and offered restitution. The state offered to pay for the excavation of their anonymous graves and for DNA analysis which alone could identify the corpses, once they had been located. The government, however, did not have the resources to fully implement its own legislation, and the work of recovering the historical memory of the period was largely left to non-government organisations such as La Plataforma de Niños Robados (The Forum for Stolen Children) and the Asociación para la Recuperación de la Memoria Histórica (The Association for the Recovery of Historical Memory), among others. By the end of 2010, for example, graves had been located in 359 villages of Andalusia where about 47,000 victims were buried.

Verónica Sierra's new book on the prison correspondence of those incarcerated by Franco contributes to this common enterprise dedicated to the rescue of a historical memory, after decades of silence (Sierra Blas, Cartas presas). Her aim, like those searching for the bodies, is to give Franco's victims proper recognition and to restore some human dignity to their fate. As the historian José Alvarez Junco put it:

It is a question of providing some moral reparation to the descendants of the victims, publicly recognizing that what happened was unjust, and that their ancestors were worthy people who suffered a fate they didn't deserve. (Alvarez Junco)

Her discussion of prisoners' letters and their life stories goes some way to acknowledging the dead, the imprisoned and the desaparecidos of Franco's Spain.

Verónica Sierra is a leading member of the small group of scholars at the University of Alcalá de Henares dedicated to the historical study of written culture. ${ }^{1}$ She approaches the subject, therefore, as a cultural historian with a strong sense of the importance of writing in extreme circumstances like imprisonment and impending execution. Her previous work analysed another corpus of letters associated with the Spanish Civil War: the letters sent from the Soviet Union by children evacuated there in 1937 by Republicans from Spain's northern ports as Nationalist troops closed in on the Basque provinces (Sierra Blas, Palabras huérfanas). Using their diaries and sketches, Sierra recovered the sad fate of these forgotten children who never returned home to Spain, and whose letters to their loved ones were collected by the Franco regime to assist the identification of republican sympathisers. 
She turns now from the writings of children to letters from prisoners. Her book is not a compilation, but a scholarly study structured around four main chapters. Having introduced her corpus and outlined the prison as a 'graphic universe,' she discusses the place of writing within the penitentiary system, ranging from graffiti to the 'imposed memoirs' which the authorities demanded from inmates. Her second chapter discusses what prisoners were officially permitted to write about and what was banned, and the avenues of secret communication which prisoners opened up for themselves. She treats prisoners and their families as both reading and writing communities, sharing the same concerns and values in spite of their limited literary competence. Chapter 3 discusses prisoners' petitions and the last chapter analyses farewell letters by those about to die.

It is believed that 280,000 people were imprisoned under the Franco regime. Half a million others had gone into exile, over 100,000 had disappeared without trace and about 350,000 had died in the war itself. Those of us who are not in close touch with Spain may sometimes forget that the repression did not end in 1939 when the Nationalists won the war. It continued up to Franco's death in 1976. The contemporary novelist Almudena Grandes significantly entitles one sequence of her impressive novels of the post-Civil War years 'Episodios de una guerra interminable.' This interminable war imposed decades of fear and silence.

Sierra has located a corpus of about 1500 letters written in prison, of which about 20 per cent are embedded in diaries, autobiographies and memoirs, published or unpublished, preserved by the families of the prisoners. There may be only one or two letters reproduced in any one book of memoirs, so that retrieving them is a complex task which requires considerable patience. The rest of the corpus is in public archives, and the letters are there because they never reached their intended destination. Instead, they were intercepted by the authorities and used to identify opposition sympathisers. Many letters were certainly destroyed by their recipients, because they could be incriminating and keeping them was too dangerous, or perhaps because families simply wanted to forget the Civil War and their experience in it.

Prisoners overcame the shortage of writing materials as well as prison censorship, even if this made their letters formulaic or stereotypical and even if they had to lie about their health and hide their fear and anxiety. The prison was a 'graphic universe,' generating an abundance of writing of a particular kind. In prison, writing was a remedy for isolation and terror, a therapy to overcome the suffering of captivity, a weapon of resistance, and a means of affirming personal identity in the face of a repressive system which tried to destroy it. Writing was synonymous with life. 
Sierra gives not so much 'history from below' as a 'history from the inside' or 'history behind bars,' which she hopes will produce a fairer and more democratic history of the Francoist repression. She has great respect for the authors and recipients she presents, desperate writers producing letters in extreme circumstances and in the hope of freedom.

Some prison writings were imposed by the authorities, who wanted to know more about the prisoner's immediate past in order to classify the severity of his or her crimes and determine appropriate punishment. Both the authorities and the prisoners themselves collected references about their past from their local villages and neighbourhoods. Some kept prison diaries; others kept brief notes which they re-ordered into an autobiographical memoir later on after their release; some told their experience to a third party who wrote in their name, perhaps because they could not write themselves, or perhaps because they were going to be executed. Some writers wanted only a few copies to circulate between friends and family; others wanted to give their memories as much publicity as possible.

Prisoners wrote letters to petition the authorities for better medical treatment or news of their family's whereabouts. Their families, in turn, asked for the personal effects of executed prisoners to be returned to them. All such pleas had to show subordination and obedience, and to be written in a neat and respectful hand. Their rhetoric of submission deployed stereotypical formulas expressing deference, humility and gratitude in advance for the favour they sought. They dutifully regurgitated phrases from official propaganda, referring to 'el domino rojo' (the red supremacy), 'el periodo marxista,' 'la dominación rojo-separatista en Vizcaya' (the red-separatist domination of Biscay). They echoed politically correct phrases like 'Dio salve a España,' and 'el glorioso Movimiento' (i.e. Franco's 'glorious' Nationalist Movement). Respect was shown by good, clear handwriting; such a letter often required some knowledge of juridical vocabulary and, for this, many prisoners resorted to a delegated writer. Writers justified their innocence, and described how they were captured, turning their petitions into a form of miniature autobiography.

There were, of course, alternative methods of secret communication with those on the outside, using codes, invisible inks made of lemon or vinegar, or bribing the prison staff to transmit a letter. Incoming messages were smuggled through on visiting days, sewn into clothing, hidden in toothpaste tubes or in false bottoms of cooking pans. Prisoners were not passive but actively resisted the prison system.

Sierra leaves the most interesting and moving part of her analysis to last, in her discussion of the cartas en capilla, or 'chapel letters.' These 
were letters of final farewell, written by condemned prisoners who were about to be executed, either by firing squad or by strangulation with a wire garrotte. Facing imminent death, prisoners wrote their last words to their loved ones, to proclaim their innocence, and console their family. They asked for forgiveness, they weighed up the balance of their lives, they gave advice, and they made their final requests so that some letters have a testamentary quality. Sometimes they wrote several pages and sometimes a brief sentence. If they had no paper, they tore out a page from a book to write on, or in extremis they wrote on clothing, cigarette packets, on furniture or on the walls of the chapel. Other prisoners came later to retrieve their messages.

Final letters proclaimed a moral victory over their captors, and claimed to face death with a serene conscience. Writers usually insisted that they had no regrets about their conduct. These ideas were well encapsulated in the letter Joan Curto Pla wrote to his wife from prison in Tarragona in 1939:

My beloved wife:

I don't know when you will read these lines. I have been perfectly relaxed for some time now ... My conscience now is like a lake full of deep clear water over which storms and squalls pass without disturbing it or stirring it up. I do not regret my life nor how I thought, how I felt, how I worked. My daughters can lift up their heads proudly knowing that their father was a martyr for an ideal and the victim of ferocious cruelty. I leave them my example to follow and my memory as an endless source of pride. (Sierra Blas, Cartas presas, 237)

The condemned tried to control the way in which they would be remembered, and in their letters they represented themselves as honourable defenders of peace, justice and liberty looking ahead to a new dawn. Thus Alberto Albiñana wrote to his children:

When our Army triumphs and you see the flag, kneel down and kiss it. This is what your father lost his life for, and for it you must give up your own if the need arises. The Motherland is built on the strength and sacrifices of each of its subjects, offer it your own grain of sand, as I have already done. (Sierra Blas, Cartas presas, 239)

Sierra also includes some letters from Nationalist prisoners whose letters, in contrast to those of Republicans, defended 'God and Spain.' These Francoist victims of the Civil War, however, were already fully honoured by the victorious regime, and consequently Sierra's main attention is devoted to the Republican victims. 
Priests and monks accompanied the condemned in their last moments, to confess them, pray with them, and advise them if required. They also acted as copyists and intermediaries of their last letters. As a result, confessional and Christian language infiltrated the last letters, for instance in their requests for forgiveness, in expressions of forgiveness for their enemies, in their belief in eternal life, which was present in letters of condemned men both of the left and the right. Alberto Albiñana wrote to his children from Guadalajara prison in 1936, expressing no desire for vengeance:

I forgive all my enemies with all my heart and you should all do the same. May God forgive me as I forgive them. (Sierra Blas, Cartas presas, 266)

Others on the left included outright hatred of religion in their letters; obviously these were authors who were not going to ask a cleric to transmit their final letters.

Writing in the face of death produced a special kind of life-writing; it was brief and self-justificatory, and it was composed by authors who were desperate to be well-remembered. It sought to influence and advise the children of the condemned, so that they would respect his or her memory and continue the anti-fascist struggle in their hearts. Letters sometimes closed with an agonising sense of finality:

'I am sorry, my baby,' wrote one condemned prisoner to his wife, 'I am running out of paper and out of life, so I will use what I have left to send you my last thought with all my love, all my life, all of it, everything, absolutely everything, with the biggest hug for all time from your Fernando. Forever yours until death'. (Sierra Blas, Cartas presas, 255)

Like the letters of soldiers in the trenches in the First World War, prisoners' letters were coloured by fear of death, and an intense desire to console.

Above all, the letters of final farewell were to be instrumentalised by a cause-something which their authors sometimes foresaw and facilitated. Instead of being intimate and private, they were used by both sides as weapons of propaganda. At this point Sierra's analysis becomes an investigation of historical memory and its manipulation. One emblematic example is that of the Trece Rosas (Thirteen Roses), female members of the socialist youth movement who were shot along with 44 other young socialists in Madrid's eastern cemetery on 5 August 1939. The myth of the Trece Rosas spread by word of mouth, enhanced by the fact there was no substantial proof against them, and above all by the fact that seven of them were minors (in other words, under 21 years old). Their last letters 
from the prison of Ventas have been republished many times and films made of their lives and deaths.

'Let my name be remembered in history,' wrote Julia Conesa, one of the thirteen, to her mother and brothers before she was executed, and her wish was to be fulfilled many times over. (Sierra Blas, Cartas presas, 272). This is a spectacular example of how final letters could become public monuments. They were used as instruments of propaganda and denunciation, testimonies to the on-going political struggle, symbols of heroism and either Communist/Republican or, on the other side of the conflict, of Catholic martyrdom. In fact, something similar to the fate of the Trece Rosas happened to the young Claretian missionaries of Barbastro (Huesca), executed by republicans in 1936, now honoured by a martyr's museum. Their final letters were circulated and read aloud, in schools, taverns and churches, published widely in periodicals and broadcast on the radio.

Verónica Sierra achieves a remarkable synthesis of sensitivity and objective treatment of her material. Her book pays implicit homage to the dead, but without the loaded language and ideological parti pris which has characterised the topic in the past. She vividly shows us prisoners awaiting certain violent death, trying to make sense of their lives and to manage their own legacy. Only in a short epilogue does the author's personality fully emerge, as she offers a few personal reflections and concludes with a 'canto a la libertad.'

Her study illustrates the value of personal correspondence not only for our understanding of life writing in all its manifestations, but for a balanced view of history in a broader sense. Until the mid-twentieth century, after all, correspondence dominated communication practices. It remains an especially valuable window into the lives, values and experiences of 'ordinary people,' the subordinate and not necessarily educated classes whose writings never aspired to the status of literary autobiography or a journal intime. The writings of the educated, of the upper and middle classes, are by now well known to us, and they do conform more frequently to standard literary genres. ${ }^{2}$ But to fathom the experiences of less-educated social strata, the historian must unearth their correspondence.

The correspondence of the lower classes surfaces for us at exceptional and dramatic moments of separation, like war, emigration and, in this case, imprisonment in Spain during the Civil War and its aftermath. In the writings of ordinary soldiers in the First World War, we can glimpse the wavering allegiance of soldiers to the national cause, or more often their indifference or hostility towards it. This material enables us to assess how people internalised or resisted the official discourse of national 
identity. Similarly, the writings of emigration give the historian a perspective on mass migration based on individual experiences, privileging individual agency in contrast to sociological assessments of migration patterns, in which personal choices are submerged in a mass of statistical generalities. Verónica Sierra's book performs a similar task for historians, in bringing a lost historical memory to light after a long night of silence, and thus providing a more balanced view of the Franco period as a whole. Her work deserves a translator; but English readers can at least refer to her previous article published in The European Legacy in April 2011 (volume 16, number 2).

\section{WORKS CITED}

Álvarez Junco, José. 'Un medida pedagógica', El Païs, 26.07.2017.

Blaak, Jeroen. Literacy in Everyday Life: Reading and Writing in Early Modern Dutch Diaries, translated by Beverley Jackson. Leiden: Brill, 2009.

Lyons, Martyn. The Writing Culture of Ordinary People in Europe, c. 1860-1920. Cambridge UK: Cambridge University Press, 2013.

Sierra Blas, Verónica. Palabras huérfanas: Los niños y la Guerra Civil. Madrid: Taurus, 2009.

Sierra Blas, Verónica. Cartas presas: La correspondencia carcelaria en la Guerra Civil y el Franquismo. Madrid: Marcial Pons, 2016.

Simonet-Tenant, Françoise. Le Journal intime: genre littéraire et écriture ordinaire. Paris: Téraèdre, 2004.

\section{ABOUT THE AUTHOR}

Martyn Lyons is Emeritus Professor in the School of Humanities and Languages at the University of New South Wales in Sydney. His research interests lie in the history of reading and writing practices in Europe and Australia, and his most recent books were The Writing Culture of Ordinary People in Europe, c. 1860-1920 (Cambridge University Press, 2013), and Approaches to the History of Written Culture: A World Inscribed, edited with Rita Marquilhas (Springer International, 2017). He is currently preparing a study of the impact of the typewriter on writing practices.

\section{NOTES}

1 Seminario Interdisciplinar de Estudios sobre la Cultura Escrita. See www.siece.es.

2 On personal journals, see, for example, Simonet-Tenant. On diaries, see, for example, Blaak. On the correspondence of lower-class writers, see Lyons, and its bibliography. 